\section{Biometric characterization, water absorption curve and vigor on araçá-boi seeds}

\author{
Marcela Liege da Silva Moura, ${ }^{1}$ \\ Edvan Alves Chagas, ${ }^{2}$ \\ Oscar José Smiderle, ${ }^{2}$ \\ Rosemary Vilaça, ${ }^{2}$ \\ Pollyana Cardoso Chagas, ${ }^{3}$ \\ Elias Ariel de Moura, ${ }^{3}$ \\ Eliel Eleutério Farias ${ }^{3}$ \\ ${ }^{1}$ Post-graduation program in Biodiversity \\ and Biotechnology, Rede \\ Bionorte/UFAM/UFRR; ${ }^{2}$ Brazilian \\ Agricultural Research Corporation \\ (Embrapa), Productivity Research \\ Scholarship - CNPq; ${ }^{3}$ Agricultural Science \\ Center, Federal University of Roraima, \\ Brazil
}

\begin{abstract}
Araçà-boi is a fruit, which awakes great interest for presenting pulp of quality. Their seeds are recalcitrant and present a relatively short period of viability. The water absorption by seeds is a mechanism of growth resuming of the embryo with a subsequent of the tegument breakage by the radical. The seed electric conductivity is a vigor testing is directly related to the membrane permeability. Study of the curve of water absorption by the araçá-boi seeds will contribute to characterize their germination process. In this context, studies concerned with seeds were conducted, which characterized the mass, biometrics, water content, electric conductivity and water imbibition by seeds. It was found that the population of plants established in Manaus-AM produces small, medium and large seeds and which present $70.2,68.2$ and $47.5 \%$ of moisture. The greatest water increase takes place in the first hour of absorption, regardless of the size of seeds and water absorption velocity is not influenced by their size. The imbibition curves characterized in the 144-hour period, independent of the size of seeds, show changes of two physiological phases. Both the large and medium seeds present smaller conductivity values, obtaining smaller percentages of germination for possessing increased vigor indices.
\end{abstract}

\section{Introduction}

The Araçá-boi (Eugenia stipitata ssp. Sororia McVaugh) is a promising alternative crop for the Amazon countries and although it is not yet widespread, arouses interest due the phys- ical chemical characteristics of its fruit and sensory attributes of good acceptability. ${ }^{1-3}$ Despite the ease of cultivation, the Araçá-boi has physiological characteristics, which requires care in seedling production process, since they have recalcitrant seeds which cannot tolerate dehydration or low storage temperatures and also feature viability period relatively short.The reserve substances and other compounds present in the seed are essential for the propagation of native species because they are related to germination process, storage potential and seedling establishment. ${ }^{4}$

Carvalho showed that the larger seeds were better nourished during its development and so their embryo are well constituted and have a higher amount of reserve substances, consequently, are most vigorous. The largest amount of reserves increases the probability of success in seedling establishment $t^{5}$ because it allows for longer survival in unfavorable environmental conditions. Popinigis ${ }^{6}$ concluded that the size of the seed, in many species, is indicative of the physiological quality and so the biometric characterization of fruits and seeds is very important for taxonomy, identification of varieties and confirmation the occurrence of phenotypic variation. ${ }^{4-}$

${ }^{18}$ The germination is initiated after absorption of water, with subsequent rupture of the seed coat and further development of the radicle and main root. The absorption phase follows the standard in most species where the first phase occurs rapidly due to the osmotic potential difference between the seed and the substrate. ${ }^{16}$ In second germination phase characterized by a drastic reduction in the absorption speed and increasing solute diffusion for high rate metabolism regions, mainly in the embryo. Finally, in Phase III begins with the issuance of the primary root, and only occurs in non-dormant seeds. Thus these three phases generate the seed water absorption curve contributing to the standardization of tests for evaluation of seed quality. ${ }^{8-12}$ Although the understanding of germination course there are other important reviews. The electrical conductivity is considered as a seed vigor test, which evaluates the electrical current through of conductivity in the soaking solution and the loss of inner cell leached into the external environment involving biochemical processes entirely related to the disruption of cell membrane systems. ${ }^{17}$ In the electrical conductivity of seed testing, the lowest values correspond to lower release of exudates indicating greater vigor. In this context, the objective was to perform biometric characterization, get the water absorption curve and the study of the effect of Araçá-boi seeds.

\section{Materials and Methods}

\section{Material collection}

The seeds used in this study were derived
Correspondence: Marcela Liege da Silva Moura, Biodiversity and Biotechnology Net of Legal Amazonia, Doctorate Program in Biodiversity and Biotechnology, Bolsista CNPq., Campus Paricarana. Av. Cap. Ene Garcez, n ${ }^{0} 2413$, Bairro Aeroporto, 69310-000 Boa Vista, Roraima, Brazil. E-mail: marcelaliege@yahoo.com.br

Key words: Viability; recalcitrant seeds; seeds; germination; native fruit.

Acknowledgements: authors would thank the National Council for Scientific and Technological Development $(\mathrm{CNPq})$ for the doctor scholarship and scientific research and the State of the Environment Foundation Environment and Water Resources (FEMARH) for financial support.

Contributions: the authors contributed equally.

Conflict of interest: the authors declare no potential conflict of interest.

Received for publication: 24 October 2015. Accepted for publication: 12 December 2015.

This work is licensed under a Creative Commons Attribution-NonCommercial 4.0 International License (CC BY-NC 4.0).

(C)Copyright M.L. da Silva Moura et al., 2016 Licensee PAGEPress srl, Italy

International Journal of Plant Biology 20165; 7:6265 doi:10.4081/pb.2016.6265

from fruits of different populations of $E$. stipitata in different stages of maturation collected in Manaus, Amazonas, in November of 2013. The seed extraction was performed manually followed by washing in running water with a sieve of aid for the complete removal of mucilage. Then were dried in the air for 2 hours with an average temperature of $25^{\circ} \mathrm{C}$. Then the seeds were quantified and grouped in three sizes in accordance with the masses: i) Large: seeds with more than $0.78 \mathrm{~g}$; ii) Medium: seeds between $0.77 \mathrm{~g}$ and $0.19 \mathrm{~g}$; and iii) Small: seeds less than $0.18 \mathrm{~g}$.

\section{Biometrics seeds and weighing the material}

One-hundred and fifty seeds were selected from each group, which remained in $25^{\circ} \mathrm{C}$ environment during 12 hours and then was obtained mass (g) with accuracy of $0.001 \mathrm{~g}$. To determine the biometrics was measured length, width, and thickness (mm) of the seed with a digital caliper.

\section{Water content}

Twenty seeds were used for each group and placed in plastic cups with four replications of five seeds. The seeds were soaked in water for 72 hours and weighed on a precision balance, 
$0.001 \mathrm{~g}$, were then placed in an oven at $105^{\circ} \mathrm{C}$ for 24 hours. ${ }^{19}$ The seed water content was calculated as follows:

$$
\text { Water content }(\%)=100 \times(\mathrm{P} 1-\mathrm{P} 2) / \mathrm{P} 1
$$

where: $\mathrm{P} 1=$ mass of the wet sample; $\mathrm{P} 2=$ mass of dry sample.

\section{Electrical conductivity}

The pattern of leaching of exudates was evaluated for seeds of the three groups, using four replications of 25 seeds, previously weighed on analytical balance with a precision of $0.001 \mathrm{~g}$ and packed in containers with $75 \mathrm{~mL}$ of distilled water, kept in $25^{\circ} \mathrm{C}$ ambient temperature, for 24 hours. After the period of soaking, solution was stirred gently and the conductivity reading performed with a conductivity meter. The results are divided by its initial weight of the seed. Values are expressed in $\mu \mathrm{S}$ $\mathrm{cm}^{-1} \mathrm{~g}^{-1}$ for seed.

\section{Soaking}

We used 100 seeds randomly chosen from the three groups, placed in plastic cups, with four replications of 25 seeds. It was determined the initial mass of each repetition in each cup was and so added $75 \mathrm{~mL}$ of water in these. The seeds were soaked in water for periods of $1,2,3,5,9,15,24,48,72,96,120$ and 144 hours at $24^{\circ} \mathrm{C}$ to room temperature.

At each time interval, shorter initially (1 hour) and then higher (24 hours) were performed successive weighing to evaluate the variation of the humid mass in each period and time. Every time the seeds were removed from the water and completely dry in absorbent paper, weighed and returned to the plastic containers.

The soaking of the seeds was measured by variation of mass identified in successive weighing up to 144 hours.

The data were analyzed by the computer program Sisvar. ${ }^{11}$ The values were submitted to analysis of variance and the means compared by Tukey test at $5 \%$ probability. ${ }^{13}$

\section{Results and Discussion}

The results of the determination of individual mass of 150 seeds confirm that the size separation performed in the initial sample into three groups composed of large seeds, medium and small was effective (Table 1). The values of the mean of the masses obtained for the seeds were following: $1,37 \mathrm{~g}, 0.64 \mathrm{~g}$ and $0.08 \mathrm{~g}$ for large seeds, medium and small, respectively. The values recorded in this study for large and medium seeds were superior to those obtained by Anjos and Ferraz, ${ }^{20}$ which studied

Table 1. Mean values (Average of 25 seeds) of length, width, diameter and mass of the Araca-boi seeds used in this study, Boa Vista-RR, 2014.

\begin{tabular}{lcccc} 
Seed sive & Length, $\mathrm{mm}$ & Width, mm & Diameter, mm & Mass, g \\
Small & 7.17 & 6.09 & 4.90 & 0.08 \\
Medium & 14.27 & 10.55 & 8.06 & 0.64 \\
\hline Large & 19.68 & 13.04 & 9.67 & 1.37 \\
\hline
\end{tabular}

Table 2. Mean values of electrical conductivity (EC) of immersed seeds in water within 24 hours germination and seedling emergence speed obtained from Araçá-boiseeds at the end of 100 days.

\begin{tabular}{lccc} 
Seed sive & EC (1S cm $\left.\mathrm{cm}^{-1} \mathrm{~g}^{-1}\right)$ & Germination (\%) & Emergence rate (index) \\
Large & $0.79^{\mathrm{a}}$ & $71^{\mathrm{a}}$ & 1.94 \\
Medium & $1.70 \mathrm{a}$ & $64^{\mathrm{a}}$ & 1.45 \\
\hline Small & $12.04^{\mathrm{b}}$ & $2^{\mathrm{b}}$ & 0.06 \\
\hline
\end{tabular}

a,b Means followed by the same letter in the column do not differ by Tukey test at $5 \%$ probability.

the morphology, germination and water content of the seeds found Eugenia stiptata average weight of $0.49 \mathrm{~g}$. Thus the seeds obtained from the plant population established in Manaus-AM, were separated into three groups and were called small, medium and large. The results of the average water content of the seeds, the mean values of the humidity determined in an oven at $105^{\circ} \mathrm{C}$ for 24 hours were $47.5 \%$ for large seeds, medium seeds to 68.2 and $70.2 \%$ for small seeds.

Carvalho and Nakagawa, ${ }^{8}$ demonstrated that the cotyledon seed finalize Phase I with water contents between 35 and $40 \%$ and from these levels would begin to Phase II. However these phases may be lengthen or shorten being dependent on properties inherent to seeds and environmental conditions.

Through statistical analysis of the results of water absorption there was no significant interaction between the sources of variation, seed size and immersion period.

The water is a factor that exerts decisive influence on the seed germination process. Rehydration tissue results from the absorption of water by the seeds with intensification of respiration and other metabolic activities, which provide energy and nutrients for the resumption of growth of the embryonic axis. When it absorbs water the seed cotyledons swell which causes the disruption of the seed coat facilitating the emergence of the root hypocotyl axis and other internal structures of the seed. ${ }^{21}$ Therefore when starting the soaking process this will result in seed germination, ${ }^{5,7-16,19-23}$ following the life cycle distributing plants in nature. ${ }^{2}$

The Figure 1A depicts the wet weight of the seeds and so checking up the progress of cases through the water absorption curves by seed small, medium and large over the observed period.

In Figure 1B, we can see through the approximation of wet mass curve of large (L), medium (M) and small seeds (S) of Araçá-boi the two physiological stages of soaking.

Regardless of the class the seeds present the phase I occurred in the first two hours, when there was rapid increase in the wet weight from this period there was stabilization of water absorption. Which characterizes the phase II (stationary) of the curve. ${ }^{10}$ on germination of two types of studies umezeiro (sour and sweet) as a function of pre-soaking of the endocarps water $(0 \mathrm{~h}, 48 \mathrm{~h}, 96 \mathrm{~h}$ and $144 \mathrm{~h})$ found no effect of this treatment on germination.

Carvalho NM and Nakagawa $\mathrm{J},{ }^{9}$ demonstrated what the soaking is a purely physical process associated with the properties of colloids and depends on the binding of water to the seed matrix..$^{23}$ points out that the matrix component is primarily responsible for the movement of water at the start of soaking but with greater availability of free water osmotic component becomes very participatory.

In Figure $2 \mathrm{~A}$ there is an increase in the amount of water in seeds, in 144 hours of soaking. In Figure $2 \mathrm{~B}$ there is a greater increase in the amount of water the seeds in the first two hours of soaking. In the following hours monitoring the seeds maintained constant pace in the gain amount of water (mass) approaching for medium and small seeds of Araçá-boi.

The process of the seed water soaking sequential triggers metabolic changes that culminate in root protrusion when referring to non-dormant viable seeds. ${ }^{8}$ The seeds evaluated in this study since they presented dormancy showed no protrusion of radicle at the end of the weighing performed for 144 hours of immersion and thus not observed the Phase III. Lima J and colleagues ${ }^{14}$ found low germination of freshly collected seeds of Caesalpinia ferrea attributed to the low gain during soaking. This would be showing that the seeds pre- 
sented cutaneous numbness. Similar result was observed in this study for both large seeds as for medium and small Araçá-boi.

The speed of verified water absorption was not affected by seed size indicating no seed coat permeability difference of large seeds in relation to medium and small Araçá-boi used in this paper.

The imbibition curves characterized the period of 144 hours regardless of the size of the seeds showed the changes of the first two physiological stages. The first phase lasted two hours and the second phase lasted until the end of the monitoring for 144 hours immersion. In this stage the soaking of seeds remained constant showing an important step towards the standardization of vigor tests.

The average electrical conductivity obtained for small seeds, medium and large of Araçá-boi are shown in Table 2. It was observed the relationship between seed size and electrical conductivity. Small seeds showed higher conductivities, which gives an indication of lower force for greater release of electrolytes for immersion solution. Means followed by the same letter in the column do not differ by Tukey test at $5 \%$ probability. Malta and colleagues ${ }^{15}$ conducted an experiment using Coffea arabica $\mathrm{L}$. and also concluded that small seeds had higher electrical conductivity. This may be due the fact that the small seeds have more specific area that large allowing faster absorption of water and releasing more electrolytes in reading solution.

The positive correlation between the electrical conductivity, the percentage of germination and seed emergence rate index is shown in Table 2. Note that the large and medium seeds had lower conductivity values, indicating higher zips and consequently, higher percentages of germination and emergence rate higher rates (Figure 3).

The result obtained in this study indicates that the different sizes of seeds observed relate to the degree of maturity of the same and which can be proven by the high water content and electrical conductivity of small seeds resulting in reduced germination of them. However, further studies can be carried out with the aim of better understanding of this aspect in seeds from other populations.

\section{Conclusions}

The plant populations established in Manaus-AM produce small seeds, medium and large and have $70.2,68.2$ and $47.5 \%$ moisture respectively.

The largest increment of water by the seed occurs the first time regardless of the size and water-absorbing rate is not influenced by its size.

The imbibition curves characterized during this period also regardless of the size of the seeds and show two physiological stages.

Large and medium seeds have lower conductivity values and then high germination percentage because they have higher levels of vigor.
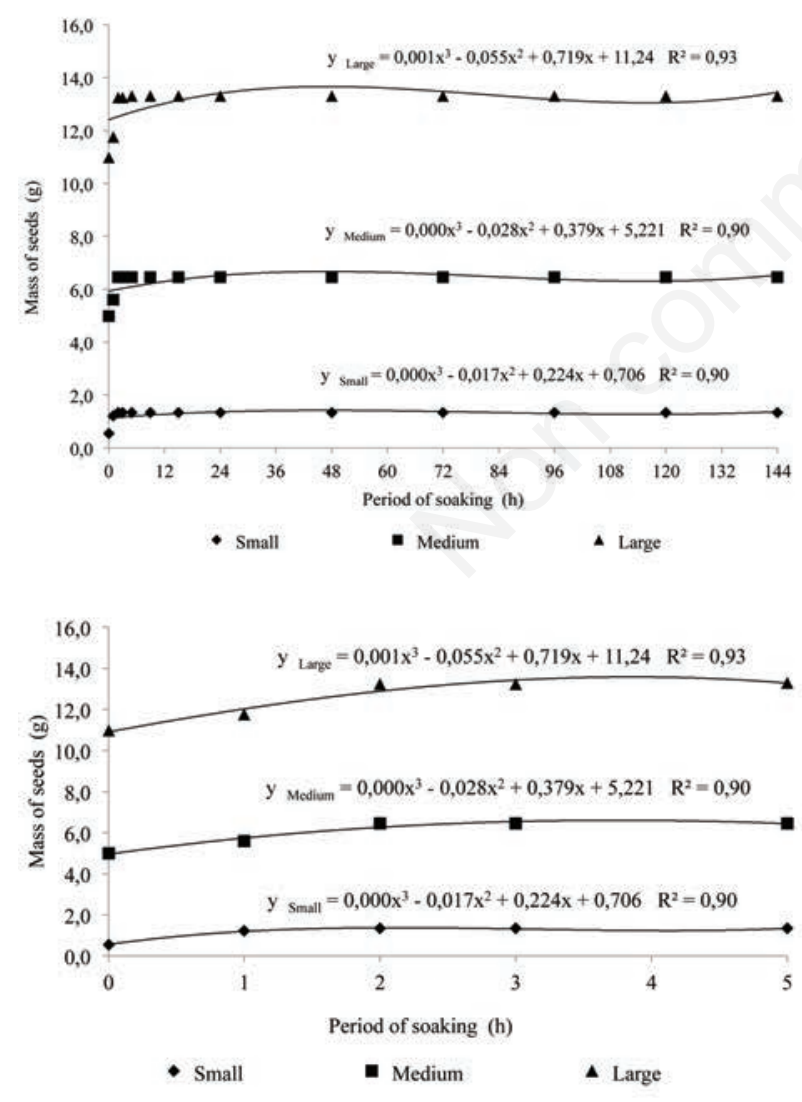

Figure 1. Mass (g) of seeds (small, medium and large) Araçá-boi soaked in water until the period of $144(\mathrm{~A})$ and $5(\mathrm{~B})$ hours.

A

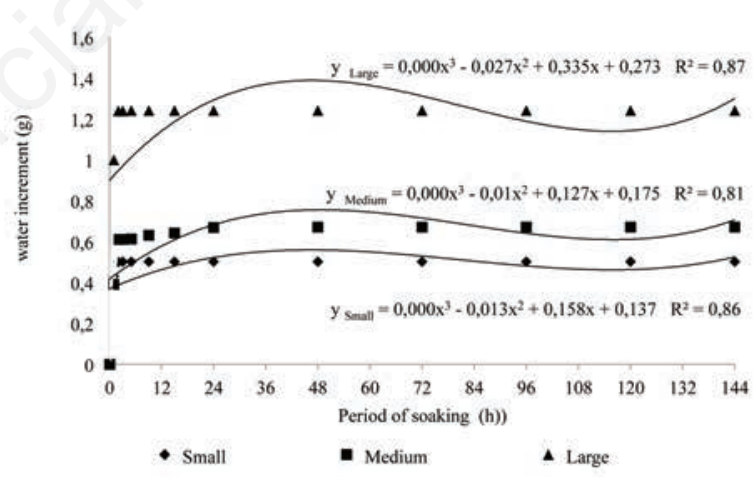

A

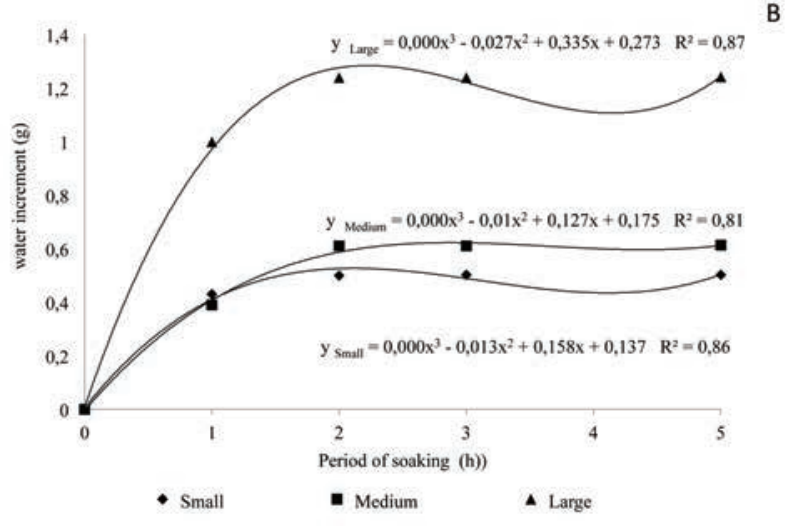

Figure 2. Water increment (g) found in the seeds (small, medium and large) of Araçá-boi immersed in water up to the period of 144 (A) and 5 (B) hours. 


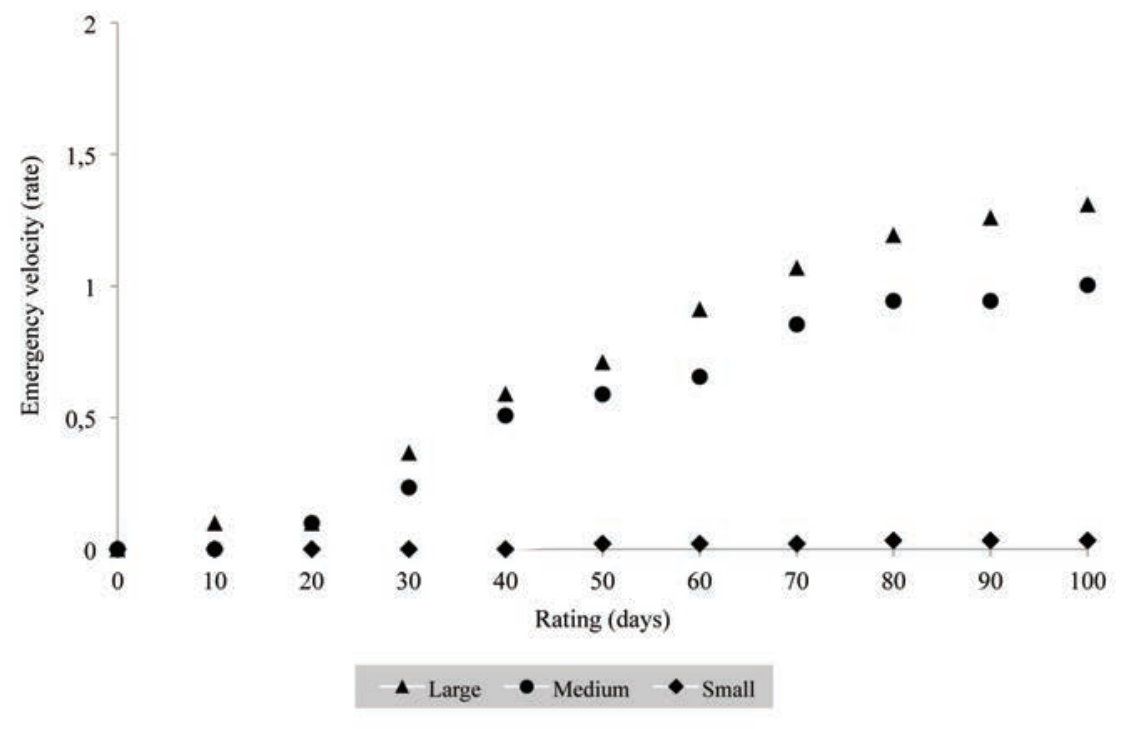

Figure 3. Emergency-Velocity (rate) of cumulative seedlings obtained from seeds of Araçá-boi up to 100 days.

\section{References}

1. Rogez H, Buxant R, Mignolet E, et al. Chemical composition of the pulp of three typical Amazonian fruits: araçá-boi (Eugenia stipitata), bacuri (Platonia insignis) and cupuaçu (Theobroma grandiflorum). Eur Food Res Technol 2004;218: 380-4.

2. Souza EB, Pacheco MV, Matos VP, Ferreira RLC. [Germinação de sementes de adenanthera pavonina L em função de diferentes temperaturas e substratos.] Revista Árvore 2007;31:437-43. [Article in Portuguese]

3. Souza Filho MSM, Lima JR, Nassu RT, Borges MF. [Avaliação físico-química e sensorial de néctares de frutas nativas da Região Norte e Nordeste do Brasil: estudo exploratório.] Braz J Food Technol 2002;5:139-43. [Article in Portuguese]

4. Mendes AMS. Eugenia stipitata ssp. Sororia McVaugh (araçá-boi) - Myrtaceae: abordagem fisiológica e morfoanatômica da semente, germinação e plântula. Degree Diss., Universidade Federal do Amazonas, Manaus, Brazil; 2011.

5. Haig D, Westoby M. Seed size, pollination casts and angiosperm success. Evol Ecol (London) 1991;5:231-47.
13. Gomes FP. Curso de estatística experimental. $14^{\text {th }}$ ed. Piracicaba: ESALQ, 2000. p 477.

14. Lima JD, Almeida CC, Dantas VAV, et al. [Efeito da temperatura e do substrato na germinação de sementes de caesalpinia ferrea mart. extul. (leguminosae, caesalpinoideae).] Rev Árvore 2006;30:513-8. [Article in Portuguese]

15. Malta MR, Pereira RGFA, Chagas SJR. [Condutividade elétrica e lixiviação de potássio do exsudato de grãos de café: alguns fatores que podem influenciar essas avaliações.] Ciência Agrotecnol, Lavras 2005;29:1015-20.

16. Marcos Filho J. Fisiologia de sementes de plantas cultivadas. Piracicaba: Fealq; 2005. p 495.

17. Marques MA, Paula RC, Rodrigues TJD. [Adequação do teste de condutividade elétrica para determinar a qualidade fisiológica de sementes de jacarandá-dabahia (Dalbergianigra (Vell.) Fr. All. Ex. Benth).] Revista Brasileira de Sementes, Londrina 2002;24:271-8. [Article in Portuguese]

18. Pinto WS, Dantas ACV, Fonseca AAO, et al. [Caracterização física, físico-química e química de frutos de genótipos de cajazeiras.] Pesquisa Agropecuária Brasileira, Brasília 2003;38:1059-66. [Article in Portuguese]

19. Ministério da Agricultura, Pecuária e Abastecimento. Regras para análise de semente. Secretaria Nacional de Defesa Agropecuária. Departamento Nacional de Produção Vegetal. Coordenação de Laboratório Vegetal. Brasília, DF, Brasil, 2009, p 365.

20. Anjos AMG, Ferraz IDK. [Morfologia, germinação e teor de água das sementes de araçá-boi (Eugenia stipitata ssp. Sororia).] Acta Amazônica 1999;29:337-48. [Article in Portuguese]

21. Borges RCF, Collaço JC Jr, Scarparo B, et al. [Caracterização da curva de embebição de sementes de pinhão-manso.] Rev Cient Eletrôn Engen Florestal 2009;8:1-8. [Article in Portuguese]

22. Andrade RA, Jesus N, Martins ABG. [Embebição e germinação de sementes de Camu-camu.] Acta Sci Agron 2006;28:499501. [Article in Portuguese]

23. Cardoso VJM. Germinação. In: Kerbauy GB, ed. Fisiologia Vegetal. Rio de Janeiro: Guanabara-Koogan; 2004. pp 386-407. 